$\begin{array}{llllll}\text { (C) EUSP, } 2018 & \text { e } & \text { ISSN 2310-3817 } & \text { Vol.6 } & \text { Sle'SiS No.2 } & \text { p.66-91 }\end{array}$

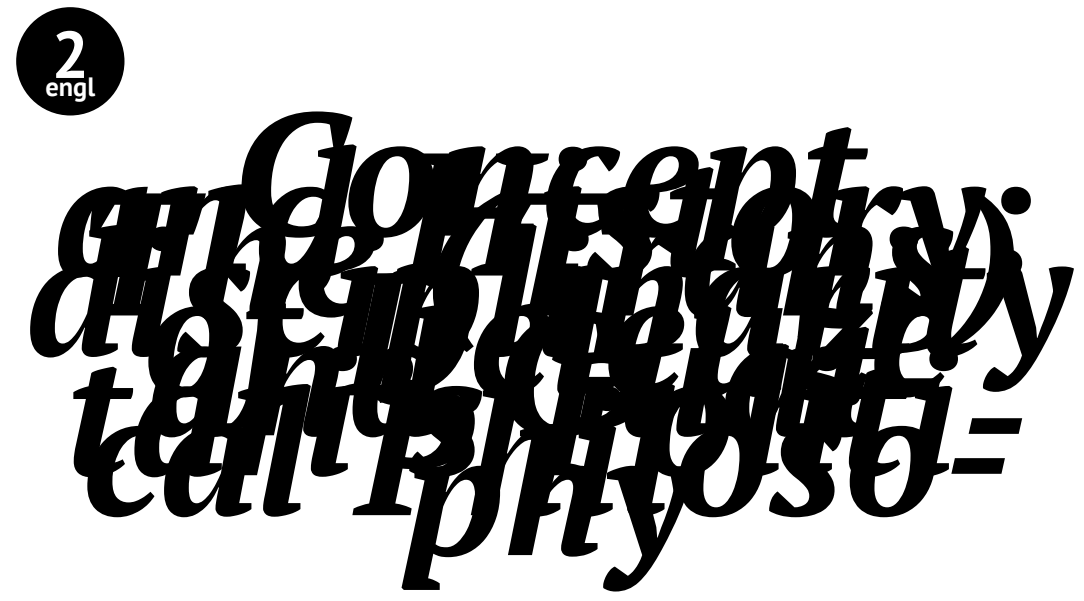

Guillaume Collett

Research Fellow in the Centre for Critical Thought, University of Kent

Giles Ln, Canterbury, Kent, UK, CT2 7NZ

E-mail:guillaume.collett@hotmail.co.uk

\title{
Concept and History: \\ The (Trans)disciplinarity of Deleuze and Guattari's Political Philosophy
}

\author{
Abstract \\ While Deleuze and Guattari's work has been criticized from a \\ number of angles, one of the most pernicious readings is Alain \\ Badiou's claim that since Deleuze and Guattari assign an \\ irreducible disciplinary modality to philosophy but not to politics \\ in their What is Philosophy? (1994 [1991]), we should consider \\ their philosophical ontology as both pre-established and \\ ultimately indifferent to concrete political considerations. By \\ examining the disciplinarity of philosophy in Deleuze and \\ Guattari, in its dynamic relation to extra-philosophical domains, \\ this article shows that far from constituting an obstacle to the \\ development of political critique, an irreducible conception of
}


philosophy as a discipline, rather, conditions such critique. The article explores this point with regard to the difference between history and becoming in Deleuze and Guattari's work, and in terms of the shift that takes place in their work from a structuralist to a machinic philosophical ontology.

\section{Keywords}

Deleuze, Guattari, machine, structure, history, becoming, event, philosophy, discipline, transdisciplinarity

\section{Introduction}

While Deleuzian politics has been attacked on a number of fronts in recent years, perhaps the most foundational of these critiques-in the sense both of its influence on contemporary debate and insofar as it challenges the very basis of Deleuzian political thought-is the claim that Gilles Deleuze's thought does not directly address political questions. Or, if it does, that it subordinates the singularity of concrete political struggles to the loose and lazy recycling of pre-established ontological considerations which, in not ultimately addressing actual history-the "inexhaustible variety of the concrete," as Alain Badiou puts it (2000 [1997]: 13)-leads to a philosophy quite literally "out of this world" (Hallward 2006). ${ }^{1}$ Perhaps the most influential of these critiques indeed comes from Badiou (2000 [1997]), who dovetails his political and ontological critiques of Deleuze on the basis that, despite ostensibly treating the multiple, it is essentially an ontology of the One, ultimately indifferent to difference, that concerns Deleuze.

From this follows Badiou's (2009) more pointedly political critique centering on the observation that in What is Philosophy?, Deleuze and Félix Guattari (1994 [1991]) only define three forms of thought-the philosophical, scientific, and artistic-with politics thereby supposedly absent. $^{2}$ This is contrary to Badiou's four "truth procedures" (science, art, love, and politics) considered as the pre-philosophical conditions of philosophy, each of which can produce independent and singular truths that

1 For a highly instructive discussion of this issue, essentially between the Badiousian and Deleuzian positions, see Alliez et al.'s (2009) “Deleuzian Politics? A Roundtable Discussion."

2 See also Mengue (2003: 45), who makes a similar point. 


\section{Guillaume Collett}

are nonetheless verifiable only after a specifically philosophical operation of conceptual superposition (this is what, in the domain of politics, Badiou terms "metapolitics") (Badiou 2006 [1998]: xxxi-xxxiii). Badiou's (2009) argument is tenuous. Reconstructing its thrust, first he claims (correctly) that in What is Philosophy?, philosophy, science, and art are all considered "creative" disciplines-for Deleuze and Guattari, this is so insofar as each creates its irreducible disciplinary content as part of an independent practice. But Badiou then suggests, rather more problematically, that as creative disciplines, and given the strong distinction between history and becoming that is indeed maintained throughout Deleuze's work, these three disciplinary groupings must be allied solely with "becoming" rather than with concrete history. He makes this assertion in order to surmise (again problematically) that, since Deleuze claims in Negotiations that his political thought is rooted in an analysis of the "history" of capitalism, his politics cannot thereby be creative (1995b [1990]: 171). Whereas, for Badiou, politics proper-ungraspable by merely "sociological" analyses of historical forms-must be understood solely in terms of the "becomings," or inaugural moments of rupture, from which history subsequently flows. ${ }^{3}$ Moreover, Badiou (2009) contends that, in any case, Deleuze is not sufficiently interested in history's concrete singularitiesthose liable to bring about genuine political change by being acted uponand is only really concerned with grand historical narratives that are indifferent to the actual social actors present therein, amounting to a theory of universal history mirroring his supposed ontology of the One.

In short, while Badiou (Ibid.) strongly endorses the notion that politics (and all disciplines) must be creative or nothing at all, his forced reading of Deleuze leads him to establish a false opposition based on an overly neat separation between history and becoming in Deleuze's work. On the one hand, we have the disciplines of creation-which are "political" only inasmuch as they are creative, but only in their own domains, never intersecting with history-and on the other, we have politics-which not being creative, as reflected by the absence of an autonomous disciplinary modality for it in their work, is thus not truly political. This leads him to effectively propose that there is no political thought as such in Deleuze, only a philosophy of history on the one hand, and on the other an only pseudo-political philosophy of extra-historical ("out of this world") creation. Badiou (Ibid.) concedes that the latter leads Deleuze to develop a conception of resistance-through-creation in his final texts-in which Deleuze (1995b; 1995c) famously articulates the notion that our presentday "control societies" function by stifling genuine creation and becom-

See the 10 October, 2016 episode of “Contre-courant”. https://www.youtube. com/watch?v=NJg49mBY3go; this discussion echoes points found in Badiou (2006 [1998]: 42-47). 
ing through the exigency of globalized "communication." But given that such creative resistance occurs, in Badiou's reading of Deleuze, outside history, where politics' effects must be necessarily played out for Badiou, he relegates Deleuzian resistance-through-creation to the status of a disciplinarily generic "ethics," rather than politics proper.

Against this reading, in this article I would like to focus on the disciplinary field and function of philosophy in Deleuze and Guattari's work, in its constitutive relation to its pre-philosophical presuppositions, especially history. To the extent that the philosophical "concept" in Deleuze is considered to express an "event" understood as a becoming breaking with history-philosophy's irreducible mode of thought being the creation or "construction" of concepts that survey the historicity of their creation but from outside it (Deleuze and Guattari 1994 [1991]: 36) -in Deleuze, philosophy would seem at first glance opposed to history, and thus methodologically unable to countenance an ontology and politics of the concretely actual and historically creative. However, I will show to the contrary that Deleuze's philosophy becomes increasingly articulated (though not conflated) with history, and that the methodological and ontological distinction that continues to be maintained between history and becoming in fact serves precisely to endow philosophy with a lens capable of critically engaging history through analysis of the counter-histories or becomings existing co-presently with it.

I will analyse this increasing articulation of (philosophical) concept and history by emphasizing Deleuze and Guattari's de-structuring or "machinic" critique of the earlier Deleuze. This point will be stressed to help show that much of the Badiousian objection to Deleuze underemphasizes important conceptual shifts in the latter's approach that issued from his collaboration with Guattari. Lastly, in this article I will seek to determine the disciplinary, or perhaps better transdisciplinary, role of the historical and extra-philosophical with regard to philosophy, so as to better situate and unpack the directly political function of philosophy's disciplinarity within Deleuze and Guattari's work.

\section{Philosophical (Trans)disciplinarity}

Our starting point is the disciplinarity of philosophy and its autonomous mode of thought (the concept) in Deleuze. Despite Deleuze's approach to philosophical thought remaining stridently disciplinary throughout his writings, I would argue that far from foreclosing genuine political thought, such philosophical disciplinarity in fact conditions the opening of thought and practice to counter-histories capable of reopening the historically and geographically circumscribed field of the possible. Deleuze's philosophical ontology has been considered, amongst other 
angles, along the lines of a realist scientism (DeLanda 2002), in terms of providing a global account of immanence equipoise between being and thinking (Montebello 2008), and via a transcendental-critical framework suited to thinking real experience (Zourabichvili 1994; Sauvagnargues 2010). Arguably with the exception of the scientistic realist reading, which I will return to briefly, these all provide valuable and accurate approaches to Deleuze's philosophical ontology. Other readings have successfully shown Deleuze's pre-Guattari work to not be indifferent to political questions but to actively engage with them. ${ }^{4}$ What these readings fail to explicitly and/or convincingly thematize, however, is the disciplinarity at stake in Deleuze's philosophical ontology, the analysis of which is essential both for a fuller understanding of his political ontology and in order to be able to specify the manner in which his philosophical ontology articulates with his politics.

What does it mean to say that Deleuze elaborates a specifically "philosophical" ontology in his pre-Guattari work, which becomes progressively "politicised" after Guattari? For this we first need to turn to the definition of philosophical thought given in Deleuze and Guattari's What is Philosophy? (1994 [1991]). In this text, they write that philosophy amounts to the mode of thought that thinks through concepts, which is to say by means of non-linguistic conceptual forms expressing "purely conceptual events" (Deleuze and Guattari 1994 [1991]: 36). An event in Deleuze's lexicon is an incorporeal entity (or a "virtual") expressed by a constructive form that expresses the event precisely insofar as the corporeal actions and passions inducing the concept's creation or construction are conceptually reacted onto, and moulded accordingly, by it (through a "quasi-" or "double-" causality [Deleuze 2004d (1969): 108-13]). Reacting onto corporeal actions and passions, the concept expresses a consistency they lack in themselves outside of their conceptual expression, though which is not simply grafted or projected onto them insofar as the event is an entity ontologically outstripping the concept that expresses it. This is the immanent dynamic of expression. The event is akin to an index or fragment of immanence, which for Deleuze is a processual entity or "becoming" emerging when concept and affect enter a constructive agreement acceptable to both parties. This is an agreement that does not privilege one half of the articulation over the other, or vice versa, from which the other half would derive its principles and functioning, as we find for instance in the Kantian operation of representationally modelling the transcendental on the empirical (Deleuze and Guattari 1994 [1991]: 38). ${ }^{5}$

4 See, for instance, the supplementary issue of Volume 3 of Deleuze Studies on “Deleuze and Marx," edited by Dhruv Jain (2009).

5 By "affect," I am referring here to specifically philosophical affect (later formulated by Deleuze as "a life" or more completely, the colon itself in the article title 
The concept is thus involved in an experimental selective procedure framing a field of consistency or a philosophical world (what Deleuze and Guattari term a "plane of immanence" [1994 (1991): 35-60]) as a determinate expression of an intensive relational space between affects, concepts, and between affects and concepts. This space is not present in the affective itself, which relates to pure vital potential, non-teleological and inactive force (Ibid.: 213); nor is it present in the concept or in conceptual relations themselves, if we consider the concept independently from a creative process of expression outstripping the concept as such (if necessarily expressed through it). Rather, it is present in the concept's impersonal perceptual vista (or conceptual "percept") on the incorporeal life counterproduced by the concept against purely affective force (i.e., expressed by it) as an activation of the inactive life of force. The composition of relations that agree (both between affects, between concepts, and between affects and concepts, and more precisely diagonally across all three dimensions at once), within a determinate putting-into-relation of these elements, can only be established through an experimental process consisting of testing their trivalent relations of composition, whereby any one of these three relations is dependent upon the other two, and vice versa. The history of philosophy conceived in this way therefore becomes an experiment in laying out a plane of immanence, whose success can only be established at the level of the result rather than the process.

This, however, is only a provisional definition of philosophical activity in Deleuze and Guattari (1994 [1991]), insofar as we are currently only treating concept-concept, concept-affect, and affect-affect relations internally to the philosophical work, or "plane of immanence." In other words, so far we are only measuring the success of their relations in terms of an abstracted notion of immanence understood solely as dimensional equality between the conceptual and the affective. From a slightly different angle, and in terms that will make more sense in what follows, so far we are trapped at the level of relations of "endoconsistency" and "exoconsistency" within and between concepts (Deleuze and Guattari 1994 [1991]: $19,22)$, respectively, as purely internal to the work, and have not yet engaged the "diagrammatic features" (Ibid.: 39, 75), or "machinic" components of the plane, through which it reaches outside the philosophical work to history and geography, to the plane's socioeconomic milieuwhat Deleuze and Guattari call the plane's "milieu of immanence" (Ibid.: 87). Before addressing this point at the end of the article, I will first explore in more detail the disciplinarity at stake in Deleuze's conception of

\footnotetext{
"Immanence: A life"), which is to be distinguished from the "affects and percepts" of art which operate by means of a radically non-conceptual means of construction (Deleuze and Guattari 1994: 164, 176-78). On the inseparability of concepts and (philosophical) affects and percepts within philosophy itself, see Deleuze (1995a: 137).
} 


\section{Guillaume Collett}

philosophy, turning then to the shift undergone by Deleuzian philosophy as he moves from an interest in structuralism toward a critical machinism opening onto history.

As hinted above, while philosophy establishes itself as a distinct discipline on the basis of an irreducible constructive form (the concept), producing a unique disciplinary entity (the event as fragment of immanence), its disciplinarity is nonetheless not methodologically autonomous when considered processually or in terms of the full extent of its generative stages, even if its end product is. Rather, from the very beginning, Deleuze's philosophical ontology has relied on a pre-philosophical transdisciplinary problematic, on the basis of which, and from which, philosophy extracts its irreducible disciplinary content. In "The Method of Dramatization" (Deleuze 2004a), a roundtable discussion from 1967 in which Deleuze defended the theses that would form his Difference and Repetition (2004c [1968]), Ferdinand Alquié notes with perspicacity that Deleuze's framework not only lacks, but indeed rejects philosophy's role in establishing a specifically philosophical object fully internal to philosophical intentionality (which is not to say that it lacks specifically philosophical content):

But I can't accept [Deleuze's] hasty rejection of the question What is this?, nor can I accept what he said, a little intimidatingly, when he claimed that no other philosopher than Plato had ever asked such a question, except for Hegel. I must confess I'm a little shocked: because I can think of numerous philosophers who have asked this question. Leibniz himself asked: "what is a subject?" and "what is a monad?" Berkeley, too, asked: "what is being?" and "what is the essence and the signification of the word being?" Kant also asked: "what is an object?” (Alquié, in Deleuze 2004a [1967]: 106)

Alquié continues by stating that when Deleuze "orient[s] philosophy toward other problems," the examples used "are not properly philosophical examples" (Ibid.: 106), using as he does biology to address the process of spatiotemporal "differenciation" (as the processual result of, for instance, the egg's intensive dynamisms as explicated in space and time through ontogenesis); and psychology and psychoanalysis to understand the question "what is truth?" (by transforming it into the question "who wants truth?," or what psychoanalytic diagnosis corresponds to this question?) (Ibid.: 106).

In his response, Deleuze doubles down on his claims, opining for instance that when Immanuel Kant asks "what is an object?," he asks this question "within the framework of a more profound question, a how question," namely "How is this possible?" (Deleuze 2004a [1967]: 106). Deleuze, though, is quick to point out that he does believe in "the specificity 
of philosophy": "the Idea, as real-virtual, must not be described in uniquely scientific terms [...] the movement of scientific concepts participates in a dialectic that surpasses them" (Ibid.: 106-07); and the question "who wants truth?" is not merely a psychological interception and diversion of a properly philosophical question, but a spatiotemporal "'figure' belonging to the very notion of truth" (Ibid.: 107), whose "dynamisms" outstrip psychology and point toward "the philosophical system" alone capable of expressing the truth that it identifies in the manner in which psychological types pose the question. In his 1994 preface to the American edition of Difference and Repetition, Deleuze will reiterate these points, stating that in this work he needed to draw on mathematics and biology (respectively, via differential calculus and the differenciation of the egg), in order to "constitute a philosophical concept of differentiation" (Deleuze 2007 [1994]: 302), to be understood as the spatiotemporal explication or expression of the intensive potential dynamisms in matter and in the idea. ${ }^{6}$ Deleuze adds that this concept is specifically philosophical, "since it is not philosophy's job to advance science or art," whereas "philosophy itself cannot advance without forming properly philosophical concepts concerning a particular [scientific] function or [artistic] construction, however rudimentary" (Ibid.: 302).

For Deleuze, the question “What is philosophy?" therefore has what we can term a "trans/disciplinary" answer, meaning that philosophy as a discipline is constituted by superposing itself onto a transdisciplinary problematic spanning the disciplines, from which it nonetheless extracts specifically philosophical entities (virtual becomings or incorporeal events, for instance "differentiation" as process). Deleuze's philosophy lacks specifically philosophical objects inasmuch as one finds there no objects, subjects, substances, Forms, monads, and so on. When such a notion does seem to appear, as we find in the key notion of "problematic Idea" from Difference and Repetition, the problematic basis of this "Idea"its intentional framing of, or point of access to, disciplinary objects-is itself transdisciplinary (even if its resultant ideational content is specifically philosophical). ${ }^{7}$ We see this in the fourth chapter of Difference and Repetition where the theory of the problematic Idea is fleshed out in relation to a myriad of disciplinary domains. Strongly influenced by $1960 \mathrm{~s}$ French structuralism, in each case Deleuze identifies a domain's differential relational elements, the series in which the structural placing of these elements assigns them a differential role and thus an essence (given the

6 See also: "science necessarily comes into play" in the "actualization" of the philosophical "Idea” of different/ciation (Deleuze 2004a: 107).

In this section I have drawn on Maniglier's (forthcoming) account of the difference between object and problem in Bachelard and Deleuze. As Maniglier puts it, "Bachelard [and Deleuze after him] replaces the correlation between subject and object with problems that institute the correlation in its very possibility." 
absence of positive terms within this ontology), and the structural operator, which, in being endlessly displaced across series, enables these elements to communicate across the open totality of the Idea's field, generating processes of "different/ciation," understood as a spatiotemporal development (differenciation) issuing from intensive structural (differential) relations (see Deleuze 2004c [1968]: 230-61). From this transdisciplinary problematic, philosophy extracts virtual entities (events) which alone account for the being or the process of different/ciation (namely, its becoming). Whereas the end result of different/ciation is the spatiotemporally actual, as studied by the disciplines (or, perhaps, more accurately, the sciences) as their proper epistemological objects, philosophy conceptually reverse engineers the process of different/ciation taking place in these disciplines in order to ontologically ground them in a shared process of becoming-actual relative to the milieu in which each becomingactual takes place.

This means that philosophy alone is able to trace the virtual, rejected pathways of an Idea's actualization in a disciplinary field-constitutively inaccessible epistemologically to other disciplines-given that any process of different/ciation implies a dense complex of potentiality, or intensive dynamisms without teleology, whose determinate expression culminates in a disciplinary object (the actual). Philosophy's disciplinary "object"-the ontological excess of becoming over becoming-actual and the conceptual or speculative reverse engineering of this process-does not exist as such abstracted from such disciplinary milieus, even if it is irreducible to them. Hence Deleuze defines the problematic Idea in terms of a "structure-event-sense" complex (2004c [1968]: 240), which as we can see has as its end result the production of a (philosophical) "event" (or as he terms it during this period, "sense-event" [Deleuze 2004d (1969): 25]). ${ }^{8}$

The best way to summarize and explicate Deleuze's position is to say that, as a "virtual philosophy" (Alliez 2004a: 85), ${ }^{9}$ philosophy alone is concerned with being (the virtual); but insofar as the notion of "virtual" is meaningless without the actual, philosophy is fundamentally incomplete,

8 As Patrice Maniglier (forthcoming) puts it, in Difference and Repetition, thought (which is the problem as such) exists at the point where two or more "structures" (here philosophy and the other discipline in question) diverge, the (philosophical) "Idea" being the transcendent object immanent to another disciplinary structure.

9 DeLanda (2002) also uses this formulation, but so as to uncritically draw philosophy into closer proximity with a scientific realism considered in terms supposedly able to adequately model the Deleuzian category of the intensive or potential. DeLanda's rejection of the Marxist basis of much of Deleuzo-Guattarian thought, and the manner in which his reformulation of assemblage theory (see DeLanda 2006) appears to have the effect of naturalizing neoliberalism's celebration of the putatively "selforganizing" market, should be enough to politically discredit such a reading of their ontology. 
since its "object," being, does not exist outside its relation to the actual. Another way of putting this is that being, for Deleuze, is becoming (Deleuze 2006a [1962]: 67), a notion that again is meaningless when conceived separately from the historical chronology away from which it becomes. As he puts it in a late interview, while history (as opposed to becoming) is not "experimental," being "just the set of more or less negative preconditions that make it possible to experiment with something beyond history," without history, "the experimentation would remain indeterminate, lacking any initial conditions” (Deleuze 1995b [1990]: 170).

To put it more succinctly, becoming should be conceived as the counter-actualization of the present, and not simply the counter-actualization of the present, and philosophy thus takes on its proper function as an anti-essentialist and anti-universalist philosophy (in excess) of the present. ${ }^{10}$ As Deleuze writes:

It behooves philosophy not to be modern at any cost, no more than to be nontemporal, but to extract from modernity something that Nietzsche designated as the untimely, which pertains to modernity but which must also be turned against it-“in favor, I hope, of a time to come." (Deleuze 2004d [1969]: 302)

As we shift from an ontology of being to an ontology of becoming, the "edge of critical modernity" relates not to the past but to a "belief in the future" (Ibid.: 302). A historicist and anti-essentialist, non-dogmatic account of being qua becoming should be sought at the level of an excess of the world, beyond it if always in strict correlation with it. It is precisely this relation of worldly excess that provides becoming with a critical lens through which to view the present, a space to think otherwise or conceive the world differently, in short, to re-potentialize the historically (and geographically) circumscribed field of the possible.

I would argue that it is precisely here that politics appears in Deleuze's philosophy. While Difference and Repetition treats historical materialism as one of its case studies in the chapter on the problematic Idea (Deleuze 2004c [1968]: 234-35), it is not enough to say, at least for later Deleuze, that politics is only one of the disciplinary domains on which philosophy must rely to extract its autonomous content. Rather, it seems that the development of Deleuze's work, chiefly after his encounter with Guattari following in the wake of texts such as Difference and Repetition, is inseparable from a re-centering of politics as the (trans)disciplinary problematic supplanting the very same role given to the problematic Idea in

10 This reading has been emphasized by, amongst others, Éric Alliez and Antonio Negri. For a clear, monograph-length account of history's active and creative role in the production of becoming, in Deleuze, see Lundy (2012). 


\section{Guillaume Collett}

Difference and Repetition. Ultimately, I will try to show how such a political problematic opens above all onto the field of history and more specifically socioeconomic milieus, politics being rooted for Deleuze and Guattari in an analysis of the history of capitalism (Deleuze 1995b [1990]: 171).

\section{Machine and Structure}

The key turning point here is doubtless Deleuze and Guattari's rejection of the category of structure on which much of Difference and Repetition tacitly depended. In Guattari's seminal text "Machine and Structure," written in 1969 but published in 1971, and commissioned by Jacques Lacan who wanted to better understand Deleuze's 1968-69 texts, Difference and Repetition and Logic of Sense, Guattari singles out two conceptions of repetition found in the former text. These come from the book's introductory chapter, "Repetition and Difference," which begins with a discussion of how "repetition," conceived by Deleuze, cannot simply be conflated with "generality" (Deleuze 2004c [1968]: 1). Guattari provides an explicitly structuralist reading of this passage, considering repetition as generality to point to structure's impotent, engendered dimension "characterized by a position of exchange or substitution of particularities” (Guattari 1984: 111), whereas repetition proper points to what in structuralist Lacanian parlance would be defined as structure's "real" kernel, namely, as Deleuze puts it on the same page of Difference and Repetition, "non-exchangeable and non-substitutable singularities" (Deleuze 2004c [1968]: 1) around which structure's formal dimension of engendered generality pivots.

As Guattari understands it, repetition as generality is left to merely reenact after the fact, and without any real novelty, the creative potentiality of the Idea's intensive differential basis. In other words, while Guattari accepts Deleuze's account of different/ciation in its ontologically constituting dimension (ontogenesis of the actual), he considers the structuralist framework used to fold into the same "structure"-and to thereby incorrectly identify as belonging to the same structural dimension-what is creative and ontologically productive in this process (differentiation) and what is impassive, sterile, and engendered (differenciation). The same tension reappears in Logic of Sense, where the category of linguistic and propositional "sense" is paradoxically considered in terms of the seeming irreconcilability of these two dimensions (Deleuze 2004d [1969]). In summary, Deleuze manages in large part to renew structuralist analysis in both Logic of Sense and Difference and Repetition, by considering structures as inseparable from the events populating them (as their expressed results), helping combat the common misconception that structure is simply antithetical to genesis; however, Guattari's decisive criticism is that 
Deleuze's framework nonetheless concedes too much of this balance to structure.

One could perhaps think that this would lead Deleuze to de-prioritize the philosophical in relation to the extra-philosophical, given that the overarching identity of differentiation (or genesis) and differenciation (or impassive effect) is captured in a philosophical concept (that of different/ciation). However, I will show that this is not at all the case. Rather, this will lead Deleuze to sever the philosophical concept from all relations to structure, sense, and language. Hence, in What is Philosophy?, the philosophical concept will now be understood purely in terms of a non-linguistic conceptual form expressing an "event" (whereas we have seen the problematic Idea amounts to a "structure-sense-event" complex) (see Deleuze and Guattari 1994 [1991]: 22). What I would like to further examine in the rest of the article is the effect this conceptual shift will have on philosophy's relation to the political in Deleuze and Guattari's work, though first we need to further disentangle the "machine" from structure.

In "Machine and Structure," Guattari (1984) will frame his overall criticism of Deleuze in terms of the need to disengage a radically nonstructuralist understanding of the "machine" or the "machinic" from processes of different/ciation, the machinic being understandable as the constructive mechanism supplanting in the problematic Idea that which articulates between the philosophical concept and extra-philosophical domains. I would argue that the primary effect of this conceptual and methodological shift is to provide a theoretical and practical framework for addressing, in a concrete and politically engaged manner, the means by which the philosophical event is able to re-insert itself into processes of different/ciation, so as to re-potentialize the actually circumscribed field of the spatiotemporally possible. In terms of the disciplinarity at stake, we saw how Difference and Repetition aims to conceptually reverse engineer processes of different/ciation occurring in any discipline, and thus to trace the historically actual (the spatiotemporally differenciated) back to its source of open potential and intensive emergence. Thus, Guattari's text offers means to improve upon Difference and Repetition's claim that the world as it is given to non-philosophical epistemological fields, including politics, is not transhistorically necessary or fixed, but the result of specific different/ciating procedures and the outcome of a contingent selection of the various alternative avenues open to processes of different/ciation. Indeed, Guattari states at the start of the text that "It seems to me vital to start by establishing the distinction [between machine and structure] in order to make it easier to identify the peculiar positions of subjectivity in relation to events and to history" (1984: 111). It is clear from the viewpoint of his later development that the, at least tacit, reliance on a structuralist framework limits philosophical critique in the early Deleuze, or more specifically, his work's ability to theorize the prac- 


\section{Guillaume Collett}

tical effectuation of such speculatively conceptualizable reverse engineering processes.

Here comes Guattari's most pointed "machinic" critique of Deleuzian structuralism: while Deleuze's conception of structure leaves room for the reverse engineering or counter-actualization of differenciated states of affairs, this reverse engineering can ultimately only take place within the terms of the structure itself, hampering the theorization of attempts to rework this structure so as to actualize alternatives. More technically still, Guattari considers the "third" element of Deleuze's general theory of structure, the displaced element (or "empty square”) enabling series' differential elements to communicate and resonate with one another across and between disciplinary fields, to be the point at which Deleuze misidentifies the machine as an operative component of structure itself (Guattari 1984: 111, n2). Guattari's point here is that the machinic has no need for structure, or more precisely it de-structures structure (it is the agent of these processes of reverse engineering), and so philosophy's critical function should consist not in conceptualizing structure itself but rather in processes of machinic de-structuring across disciplines. Inasmuch as philosophy becomes machinic critique, therefore, we can start to see how politics will come to provide Deleuze's philosophy with its transdisciplinary and problematic basis, whereas philosophy will continue to function as the discipline that theorizes this reverse engineering across disciplines (now as machinic de-structuring processes).

To be fair to Deleuze, the practice that would correspond to structure's de-structuring appears in brief spurts in Deleuze's earlier works as fragments of a manifesto for a future philosophy. Logic of Sense claims that "Today's task is to make the empty square circulate" (Deleuze 2004d [1969]: 84), whereas already in 1967, Deleuze concluded his important essay “How Do We Recognize Structuralism?" with a section detailing the notions of practice and of the subject such a circulation of the empty square-as "structuralist hero" (Deleuze 2004b [1967]: 191, emphasis in the original)-would require. ${ }^{11}$ In this essay, Deleuze contends approvingly that the "symbolic"-structuralism's most fundamental dimension and novel contribution to philosophy-displaces the naïve traditional philosophical distinction between the imaginary and the real. Nonetheless, he seems to imply that structure does not ultimately do away with this distinction, interiorizing into itself what we could call a "structuralized," or better "symbolized," imaginary which ultimately maintains the

11 See also the concluding paragraph of Difference and Repetition, which points to the practice that would be needed to affirm the univocity of different/ciation (Deleuze 2004c: 377)-which is to say the processual immanence of its structural halvesnamely the Nietzschean affirmation of eternal return (the return of the "untimely" in history). 
weak, "two-worlds" model of representation (phenomenon/noumenon). As Deleuze puts it, structure "starts with having its primary effects in itself" (Ibid.: 191), which are

ideal events that are part of the structure itself, and that symbolically affect its empty square or subject. We call them "accidents" in order better to emphasize not a contingent or exterior character, but this very special character of the event, interior to the structure in so far as the structure can never be reduced to a simple essence. Henceforth, a set of complex problems are posed for structuralism, concerning structural "mutations" (Foucault) or "forms of transition" from one structure to another (Althusser). It is always as a function of the empty square that the differential relations are open to new values or variations [...] constitutive of another structure. (Ibid.: 191)

This reading-that the structuralist event ultimately constitutes merely a symbolised imaginary-does do some violence to the original Deleuzian text, and is somewhat close to the Lacanian argument that the Deleuzian category of the virtual is nothing other than imaginary (rather than being what Deleuze calls "symbolic," a conflation Deleuze effects in this text by re-reading structuralism in terms of his own ontology). ${ }^{12}$ Nonetheless, something of this critique holds, since Deleuze and Guattari's first move in Anti-Oedipus (2004a [1972]) will indeed be to reject the synchronic dimension of the virtual, as developed in Difference and Repetition and Logic of Sense, lodging the virtual far more securely within historical chronology or diachrony. ${ }^{13}$

I will leave as an open question further examination of the extent to which Deleuze's subsequent two "structuralist" texts (Difference and Repetition and Logic of Sense) succeed in theorizing this "outside" of structure identified by Deleuze in the final section of the 1967 essay-and clearly the theory of the problematic Idea from Difference and Repetition far exceeds the narrow linguistic remit of the category of the "symbolic"-but in any case, we can certainly see Deleuze explicitly engaging the problem of re-potentialization in these works. The theory of "counter-actualization," first developed in Logic of Sense, is concerned not only with drawing away from the actualized spatiotemporal states of affairs denoted by language-by tapping into the unactualized and radically unactualizable portion of the event, its pure dimension of virtual becoming co-present with any linguistically actualized event (or, in language, "sense-event"). It is also concerned with the ethics this implies, or the manner in which the virtual portion of the event enables the ethical actor to reorient their rela-

12 See Alliez (2006: 66, n32).

13 On all these points, see Alliez (2011). 


\section{Guillaume Collett}

tion to actual states of affairs so as to act ethically in the world-which in this text entails an ethics of the event's irreducibility to worldly states of affairs (see Deleuze 2004d [1969]: 162-75). This could be taken to mean, as some critics of Deleuze argue (see especially Hallward 2006), that an ethics of the event orients the ethical actor's worldly relations towards an element constitutively lacking from the world itself (as spatiotemporal actual), and in relation to which alone the ethical actor's life takes on meaning. However, the reverse interpretation would hold that in maintaining a distance between event and state of affairs (becoming and history), and by articulating structure with its outside, the ethical (and political) actor is capable of envisaging alternative possible futures that, in challenging the fixity of the historically actual, contribute to its modification for the concrete social actors living in it.

\section{Politics of the Event}

Leaving aside a detailed exegesis of such passages in Logic of Sense and elsewhere, I would like to focus more on how this second interpretation takes on renewed force if we turn to Deleuze's collaborative works with Guattari.

Turning firstly to A Thousand Plateaus (2004b ), this text should be considered as the culmination of their attempt to found a philosophical trans/disciplinary machinic critique now explicitly framed in terms of politics. As mentioned above, the first effect of this is to diachronize becoming, though which is not to say that they do away with it. Logic of Sense develops an entire metaphysics of the virtual synchronic space of the pure event ontologically accessible to linguistic structure when freed from the representational constraints of good and common sense (as predicated on synthetic apperceptive recognition of the object and selfidentity), which moreover is conceived in terms of a more or less discrete break with the intensive durational temporality of corporeal actions and passions (and the chronological procession of propositionally denoted states of affairs) (Deleuze 2004d [1969]: 186-92). One of the primary ontological shifts reflected in the new framework adopted by $A$ Thousand Plateaus is the persistent and systematic anchoring of becoming to history. Rather than dualizing the relation between actual and virtual along two temporal and ontological axes, as we find in Logic of Sense's structuralist account-one axis polarized between intensive duration and empirical states of affairs ("Chronos"), the other between pure or subjectless time without beginning or end, and the mathematical instant without duration ("Aion") A Thousand Plateaus conjoins both dimensions ("haecceity”) (Deleuze and Guattari 2004b : 287-92). Haecceities are no longer concerned with the universal "unlimited becoming" (Deleuze 2004d 
[1969]: 4) of all events in a single Event, but rather with the "this-ness" of each concrete becoming relative to its milieu. Although the 1980 text speaks extensively of becomings, they are becomings co-present with (if still radically against) history-hence the "plateau" on becoming (chapter 10, “1730: Becoming-Intense, Becoming-Animal, Becoming-Imperceptible..."), as with all the others, has a specific date (1730), the year becoming achieved its point of greatest intensity. The now fully poststructural ontological category of the "real" intervenes decisively here as a transmutational pivot between actual and virtual, as both the window through which the actual opens onto counter-actualizing becomings and always at the same time the formalized (or semioticized) matter through which such becomings engender semiotic-material flows in a socioeconomic, spatiotemporal milieu.

This new ontological framework hinges on a second theory of language arrived at through machinic de-structuring. We see this for instance in the chapter on the "Postulates of Linguistics," which returns to Logic of Sense's model of "sense-events," but which are now specified further as "incorporeal transformations," insofar as language is now indissolubly wed (through "double articulation") to non-discursive formations in a social field (Deleuze and Guattari 2004b : 95-101). The speech act expresses an incorporeal event inasmuch as Deleuze will never fully abandon his model of conceptual expression, but this event is no longer consigned to the symbolic, having its primary effects within its own domain and so on. Being doubly articulated with the non-discursive releases structure's totalizing hold on the field of experience, since the elementary unit of language is no longer considered the differential element but rather the statement (l'énoncé) (Ibid.: 84). The statement's field and function is inseparable from the pragmatic context of its enunciation, stretching all the way to include a society's non-discursive institutional forms. The latter help determine what can and cannot be said in certain contexts, because they provide the socioeconomically embedded framework or milieu, contextualizing and semiotically-materially undergirding words' function of effecting incorporeal transformation-essentially "doing things with words," as studied by pragmatics in linguistics, but re-elaborated in terms of Deleuze and Guattari's machinism. These incorporeal transformations thus amount to sense-events whose primary effects now lie outside the domain of language itself (or outside a society's "regime of signs"), if nonetheless expressed through these signs.

While it is sometimes claimed that the one field of study missed out by $A$ Thousand Plateaus is that of philosophy, it seems rather that philosophy is given a very specific and indeed indispensable role in this text. When asked about the perplexing array of disciplines engaged by this text and the genre it places itself in, Deleuze responds "It's just plain old philosophy," insofar as it creates concepts ("rhizome," "haecceity," etc.) 


\section{Guillaume Collett}

(Ibid.: 175). However unhelpful this comment, he adds a further and much more interesting specification earlier in the interview, stating that $A$ Thousand Plateaus "invents its own fields [...] The fields are not pre-existing; they are mapped out by the various parts of the book" (Deleuze 2006c: 175). Just as for Michel Foucault (1977), Karl Marx and Sigmund Freud are authors of discursive fields that do not pre-exist them-namely history considered in terms of relations of production, and the unconscious conceived through the discursively founding notion of repression-so too should we consider Deleuze and Guattari's work to problematically frame (this time conceptual rather than discursive) fields. I would put forward the suggestion that these fields center above all on becomings co-present with (if exceeding) history, since if the philosophical concept expresses an event whose becoming separates it from historical time, in A Thousand Plateaus this nonetheless does not prevent it from intervening in history. Nonetheless, the disciplinary specificity of philosophy is retained in this text and here we see why, since its critical power comes precisely from conceptually expressing, or more accurately semiotically formalizing, events breaking with history in history. In short, if, in a way, history can be considered the primary focus of $A$ Thousand Plateaus, the (trans)disciplinary field onto which Deleuzo-Guattarian philosophy is superposed, the philosophical function of the text is thus precisely to create concepts capable of extracting becomings from history (i.e., of expressing philosophical events), which nonetheless also help account for it.

Hence, a theory of nomadism is provided, for example, through which to account for the Mongol Empire, though as a virtuality informing history machinically, which is to say independently from the level of historical subjects and objects. As mentioned earlier, the machine functions precisely as the joint between philosophical concept and its disciplinary field in the later Deleuze and Guattari, having dispensed with the notion of structure. The events the philosophical concept expresses are now inseparable from their pragmatic effects in a social field. If $A$ Thousand Plateaus is ultimately to be understood in terms of superposing a Deleuzian constructive or creative philosophical methodology onto the field of history itself (rather than onto sciences analyzable in terms of structures), its primary political effect is to be able to theorize collective thought and action in a far more potent and detailed way than in earlier works. The event is now inseparable, and considered inseparably, from its pragmatic effects and from the virtual machinic processes at work in the fields it invents. That is to say that the function of the event is now specifically to re-open the historically and geographically circumscribed field of the possible (the "stratified" milieu) by revealing the virtual machinic processes at work in that field (if strictly speaking outside its historical temporality), processes that condition different/ciation but that also exceed any latent teleology in different/ciating processes when conceptualized in terms of 
historically fixed notions of structure. A recurrent critique of structure in Deleuze and Guattari is that, while not epistemologically false-to the extent that, within certain historically contingent regimes of signs, language does function according to the structuralist principle of differentiality without positive terms (Deleuze and Guattari 2004b : 126-30)-it is blind to its own historical conditions. Thus, structuralism's ability to theorize resistance to the different/ciating processes structuring a social field ${ }^{14}$ is epistemologically constrained by the historical conditions determining a particular structure. ${ }^{15}$

Perhaps the place where Deleuze and Guattari most clearly articulate their machinic politics of the event-and here we turn more directly to history as socioeconomic milieu-is a text from 1984 titled "May '68 Didn't Happen" (2007 [1984]). Here they write that while there is always "one part" of the event (namely virtual becoming) that is always "irreducible to any social determinism, or to causal chains," crucially, the historically "possible" "does not pre-exist" the event which "creates" it (Deleuze and Guattari 2007 [1984]: 233-34, own emphasis added). This is to be understood in terms of the "new relations with the body, with time, sexuality, the immediate surroundings, with culture, work..." (Deleuze and Guattari 2007 [1984]: 234), made possible by the event's incarnation in a collective social body. But to fully understand this point we have to return to the notion of (philosophical) concept and to the role of philosophical critique in this process. As an "incorporeal transformation" expressed by a conceptual form, the event does not pre-exist its conceptual expression by a created concept, just as much as the field of the historically (and geographically) possible does not pre-exist the event. The kind of furious collective theoretical work undertaken during and in the wake of May '68 must be understood as a kind of collective "philosophical" process amounting to the attempt to bring an "event," such as May '68, to bear on a reformulation of social practice (such as the identity politics and new social movements that flourished during the 1970s).

"Philosophical" is the apt term here because this collective theoretical work (of which Deleuze and Guattari's Capitalism and Schizophrenia project was a direct continuation and extension) is conceptually oriented toward the event-and, at its most extreme or intense point, the event's impossibility (its infinite reserve of potential), as seen in the May '68 slogan "Be realistic, demand the impossible!" Moreover, this evental orientation of such collective theory is "philosophical" inasmuch as creation or

14 For instance, the individuation of subjectivity-see Deleuze and Guattari (2004b : 131-48); Guattari (1995 [1992]: 1-32).

15 This is a helpful way to understand Deleuze and Guattari's machinically historicist critique of Foucauldian "structuralist" historicism. On this, see also Hardt and Negri (2001: 28). 


\section{Guillaume Collett}

construction are integral to it: the singular and contingent manner in which the event is expressed by conceptual elaboration determinately shapes the contours of the field of possibility that an event will be able, through this conceptual elaboration, to transmit to historical actuality. In short, the continuum that exists between the virtual event's infinite potential and the restricted field of possibility in which actual history plays out, is modulated back and forth by a socially embedded practice of concept construction whose measure of success is no longer merely its degree of "immanence," but now also its capacity to express a free-which is to say, collectively desired-institution.

Deleuze and Guattari's notion of "assemblage"-touched on above regarding language's "incorporeal transformations"-is essential here to conceive of the two-sidedness of this equally theoretical-practical collective work, as well as the libidinal political economy involved. As they write, again in their article on May'68, when an event or "social mutation" appears, it can only be used to revitalize a social field if it is capable of being conceptually expressed (or semiotically formalized) by "collective assemblages of enunciation" such that they "desir[e] the mutation" (Deleuze and Guattari 2007 [1984]: 234). In other words, the inextricable twosidedness of language considered as pragmatics, and of its attendant social assemblages-always both "collective assemblage of enunciation" and "machinic assemblage of desire" (Deleuze and Guattari 2004b : 9798)-means that concepts channeling the event can only be constructed at the level of the collective social practice where the effects of re-potentialization will be felt affectively, and whose social or institutional effects will be to affectively or libidinally mould new collective agential pathways desired by the social actors. This point is better understood if we turn to the original French term for assemblage used in A Thousand Plateaus: agencement, which implies a dimension of collective agency or agential subjectivity lacking in the English translation. This closely aligns with Guattari's signal contribution to historical materialism, which is his conception of the "production of subjectivity," understood as a process internal to the economic base itself (see Deleuze and Guattari 2004b : 99; Guattari 1995 [1992]: 1-32). If the role of assemblages is thus to produce subjectivity in the very same movement through which they machinically inscribe the possibility of this subjectivity within real social and economic relations (at the level of semiotic-material flows of desire), we can see how collective concept construction could be said to express the actual historical possibilities in which this process is embedded socioeconomically.

The event's intervention in and against history, and outside monocausal "lines of economic or political causality" (Deleuze and Guattari 2007 [1984]: 234), is thus inseparable from and contingent on a collective experimental and social practice of concept creation, through which de- 
terminately circumscribed vistas on the possible are extracted from the event's infinite virtual reserve of potential. In other words, discussion of the "meaning" of a political event constitutes it as such, by retroactively establishing the determinately finite manner in which its infinite virtual potential will be used to rehabilitate and reopen staid and sedimented historical possibilities accreted in a social field. Concept creation at the collective level becomes an essential part of the event's political historicity, or of the impact it can have on actual history, and we can thus finally see more clearly how conceptually re-potentializing the possible constitutes the political dimension of philosophy in Deleuze. ${ }^{16}$

While What is Philosophy? leaves aside discussion of this kind of collective concept creation, and appears at first sight totally divorced from political questions, it too can be shown to develop a notion of conceptual event having directly political effects in history. Discussion of What is Philosophy?'s political dimension has tended to emphasize philosophy's function of "resisting the present" (Deleuze and Guattari 1994 [1991]: 108; see also Deleuze 1995b [1990]: 172) through its creative act of constructing a "plane of immanence" that, insofar as it is virtual, is "absolutely deterritorialized" from historical and geographical milieus and thus affords a point of escape from them (Deleuze and Guattari 1994 [1991]: 88). While this dimension is indeed strongly emphasized by them, stopping here would be to provide a severely limited reading of the work. If Deleuze's philosophical "exceptionalism" can be shown to remain consistent from his earliest writings to his last, this epistemological position holding essentially that philosophy is irreducible to social, historical, and psychological causes, ${ }^{17}$ I would argue that What is Philosophy?'s most interesting political thesis consists in introducing a subtle yet significant modification into Deleuzian exceptionalism, giving the act of absolute deterritorialization not only the power to become and thus resist the present, but also to react onto history.

16 The argument that Deleuze's politics amounts to re-potentializing the possible is fairly well established. See Zourabichvili (1998), and Negri (in Deleuze 1995b). However, I do not place the same emphasis on the political involuntarism such a conception of the event implies for François Zourabichvili, given the importance ascribed above to active processes of concept creation embedded in agential theoretico-practical collectives, when considering a politics of the event. My approach also differs from that of Negri, who considers this formulation to characterize better Deleuze's earlier, pre-Guattarian work, whereas I am suggesting the reverse is the case. For Negri, in early Deleuze, "politics-as possibility, event, singularity" amounts to "short-circuits where the future breaks through into the present, modifying institutions in its wake," whereas in the post-Guattari Deleuze, "instantaneous counter-actualization" is more prevalent (in Deleuze 1995b: 170), the latter of which I consider to characterize better both early and post-1984 Deleuze.

17 See Bianco (forthcoming). 


\section{Guillaume Collett}

In What is Philosophy?, Deleuze does agree with his earlier exceptionalist stance that the philosopher is not reducible to "psycho-social types" determined by history and geography, yet he now contends as well that philosophy is not entirely separable from them either (Deleuze and Guattari 1994 [1991]: 70, 88). The notion of "conceptual personae" developed in this text is designed precisely to show how philosophy can straddle both milieu and philosophy's absolutely deterritorialized plane-and there is again a strong connection between this notion and that of the event (see Ibid.: 110). The conceptual personae point to the unsynthesized or schizoid habits of the philosopher, which are typically synthetically normalized by a milieu by being actualized and expressed as these psycho-social types (Ibid.: 64). Insofar as conceptual practice consists in activating life (understood by them as inactive force in need of construction), by conceptually reacting onto affect, it thus serves to re-express (or deconstruct) the socioeconomic, and indeed biopolitical, normalization/ construction of habit-when the latter is conceived, politically, as the determinate expression or activation of inactive force by the hegemonic power relations in a social field.

The philosophical plane of immanence's "diagrammatic features," as introduced above, are thus precisely the machinic hinge between pure (unsemioticized) concepts and their socioeconomic milieus, through which concepts can have directly (bio)political effects independently of the collective assemblages examined earlier. Moreover, it is not necessary to limit this conceptual practice to the narrow, specialized field of philosophy, since this concerns, more generally, any engagement with the concept that emphasizes its dimension of pure creativity over its semiotic-material dimension of re-engineering socioeconomic flows in a social field. If I suggested earlier that considering immanence as the sole measure of a plane is to treat it internally to the philosophical work, rather than more fully in its relation to history (and geography), this was therefore only half true. If it was initially claimed that the plane of immanence inhabited by the kind of collective thought and practice made possible by an event such as May '68 should be more fundamentally evaluated by the material-semiotic flows it makes possible-and ultimately by its ability to desire itself at a collective impersonal level-rather than in terms solely of its "philosophical" immanence, What is Philosophy? thus provides a second model of politically engaged conceptual practice focused more on the creativity of the concept itself than on its utilization within collective assemblages. 


\section{Conclusions}

What, then, is the disciplinary location and functioning of politics in Deleuze and Guattari's work, if it is not, as Badiou contends, either a generic ethics of creation spanning the disciplines and deriving from a preestablished philosophical ontology, or alternatively, a philosophy of history incapable of thinking concrete and singular becomings? I have argued that politics in their work is the precise function of conceptually re-potentializing the possible. For them, politics is more accurately political philosophy, hinging on philosophy's disciplinary irreducibility which affords it unique access to the (trans)disciplinary field of conceptual becomings in history. As seen, once philosophy is wrested away from structure and opens onto the field of history, from which it then derives its autonomous philosophical content, historically contingent becomings can be conceptually expressed as philosophical events-these events or becomings not pre-existing determinate processes of philosophical concept construction aiming to account for (render "consistent"), however partially, chaos (the never fully determinable potential of the event). Although philosophical, and thus virtual, these events nonetheless articulate with a machinic dimension through which collective thought and action can re-potentialize the historically and geographically circumscribed field of the possible, having effects on the individual and collective body which are directly political and practical.

Here, I have suggested that the philosophical concept bifurcates, giving it two disciplinary fates. The first entails constructing the concept at the level of collective assemblages of enunciation which, at the level of practice, leaves behind philosophy as autonomous discipline. While, on the one hand, I have shown that history replaces the structuralist problematic Idea as the transdisciplinary basis of the philosophical concept's extraction of events, on the other, we have seen that collective thought and action's incarnation of events within a social body, at the level of machinic processes of desire, reverses the directionality of philosophical disciplinarity (the production of events), such that events can no longer be considered separately from the semiotic-material flows engineered by concept construction (as semiotic formalization) within collective assemblages of enunciation. Here it is more accurate to speak of what Guattari would later term an "ethico-aesthetic" practice where it is precisely the (aesthetic) sensation of the virtual event, or its affective charge, which is primarily used to drive creative and collective thought and action bearing on politics. Even so, extracting this sensation from the event requires a degree of conceptual elaboration within collective theorizing processes. This is where philosophy considered as irreducible discipline still main- 
tains a secondary grip on these processes as an indispensable critical tool. ${ }^{18}$

Nonetheless, a certain tension thereby establishes itself within $A$ Thousand Plateaus between Deleuze's understanding of the text as a work simply of "philosophy," and Guattari's more practically militant and "aesthetic" concerns. This crack that was opened up seems to widen if we consider the transdisciplinary "ethico-aesthetic" methodology of Guattari's late 1992 text Chaosmosis (1995) alongside the disciplinarity of What is Philosophy? from the previous year. This is the philosophical concept's second fate, which is to continue to maintain, and indeed to re-intensify, its distance from history-even when the latter is conceived in terms of incarnating collectively conceptualized events-yet precisely in order to better intervene in history against history. This was discussed in terms of the pure creative act of "resistance to the present" nonetheless taking place in and through the embodied present of its conceptual practice.

Here it is worth returning to Deleuze's claim in a late interview that his and Guattari's political philosophy is ultimately founded on an analysis of capitalism's historical development, or the structural mutations undergone by its dominant mode of accumulation (Deleuze 1995b [1990]: 171). Since if their political thought must be considered in terms of a political ontology (in excess) of the (capitalist) present, whose becomings are co-extensive with (if outside) its history, it is apt for their work to respond to one of capitalism's most significant twentieth-century mutations by itself undergoing a transformation. We saw how, indeed, around May'68 during the global 1968 uprisings-whose role as a pivotal turning point in the history of twentieth-century capitalism (if, as becoming, irreducible to it) is well documented-a conceptual shift leads Deleuze's work down a machinic path, to which we can here add that after this point Deleuze's work can no longer be understood in terms of a response to structuralism's postwar institutional and "disciplinary" territoriality. ${ }^{19}$ This latter point would need to be further developed elsewhere, but it can be suggested that the transformation of "structuralism" into "poststruc-

18 On art as the discipline that thinks the sensation of the virtual event in Deleuze, see Bogue (2003: 178, 185). Indeed, in late Deleuze and no doubt influenced by Guattari, the political category of the "re-potentialized possible" is ontologically closer to the field of art than to the field of philosophy. The event's sensory becoming corresponds to the relation "possible/real" which concerns only art, whereas the event's conceptual becoming corresponds to the virtual and concerns only philosophy, with the event's actualization concerning science and logic (Deleuze and Guattari 1994 [1991]: 177; Deleuze 2006c [1988]: 119-20). On the aesthetic dimension in Deleuzo-Guattarian politics, see Alliez (2004b).

19 On the transition from postwar "disciplinary" institutional power to post1970s modes of deterritorialized “control," see Deleuze's "Postscript on Control Societies" (1995c). 


\section{For Deleuze}

turalism" theoretically reflects the breakdown in these postwar institutional forms corresponding to a fundamental mutation in capital accumulation (essentially its breakdown by the start of the 1970s).

In this sense, we could point to a nascent, never fully developed, “second" Deleuzian political philosophy emerging roughly post-1984, in a way culminating in What is Philosophy?, which laments the failure of May '68 to historically bring about the radical social change the event promised (their text "May '68 Didn't Happen” was published that year). Conjuncturally, this post-' 84 climate should be understood in France in terms of the capitulation in 1984 of the communist faction of the Mitterrand government and the attendant waves of austerity measures introduced thereafter (a period Guattari [2009] referred to as the "Winter Years"), together with the more general creeping totalization of a globalized and later networked capitalism during this period (Deleuze's "control" and "communication" societies [1995c]). While Guattari's work will respond to the post-1984 context by re-asserting his "ethico-aesthetic" practice, indeed extending it to cover "ecosophical" (Guattari 1995 [1992]: 119-35) concerns partly designed, it seems, to counter globalization's vision of a global capitalist ecosystem, I suggested that Deleuze's work will respond, conversely, by re-asserting the dimension of philosophical irreducibility and pure conceptual creation. This has the effect of re-intensifying becoming's distinction from history within philosophical conceptualization in order, one might presume, to provide the impetus for a later (though never completed) renewed theorization of processes of re-potentialization better suited to the contemporary world, particularly in light of neoliberalism's project to systematically dismantle collectivities. ${ }^{20}$

\section{References}

Alliez, Éric (2004a). The Signature of the World: What is Deleuze and Guattari's Philosophy? Trans. Eliot Ross Albert and Alberto Toscano. London: Continuum.

Alliez, Éric (2004b). “The BwO Condition or, the Politics of Sensation.” In Discernements: Deleuzian Aesthetics/esthetiques deleuziennes, eds. Joost de Bloois, Sjef Houppermans, and Frans-Willem Korsten, 93-112. Amsterdam: Editions Rodopi. Alliez, Éric (2006). “Deleuze avec Masoch.” Multitudes 25: 53-68. https:/www.cairn. info/revue-multitudes-2006-2-page-53.html

Alliez, Éric (2011). “Rhizome (With no return).” Radical Philosophy 167 (May/June):

20 On this point, it is instructive to contrast Negri's comments on the revolutionary potential of the "general intellect" with Deleuze's far more pessimistic views on the capacity for contemporary communication and control technologies to bring about the kind of communist collectivities entailed by the notion of "multitude" (see Deleuze and Negri's discussion in Deleuze 1995b: 174-45). 


\section{Guillaume Collett}

36-42. https://www.radicalphilosophy.com/article/rhizome-with-no-return Alliez, Éric, Claire Colebrook, Peter Hallward, Nicholas Thoburn, and Jeremy Gilbert (2009). “Deleuzian Politics? A Roundtable Discussion.” New Formations 68.1: 143-87.

Badiou, Alain (2000). Deleuze: The Clamor of Being [1997]. Trans. Louise Burchill. Minneapolis: University of Minnesota Press.

Badiou, Alain (2006). Metapolitics [1998]. Trans. Jason Barker. London: Verso.

Badiou, Alain (2009). "Existe-t-il quelque chose comme une politique deleuzienne?" Cités 4.40: 15-20. https://www.cairn.info/revue-cites-2009-4-page-15.htm

Bianco, Giuseppe (forthcoming). "Philosophy and History of Philosophy. Deleuze as a Trainee Guard of Philosophy's Epistemological Borders.” In Deleuze, Guattari, and the Problem of Transdisciplinarity, ed. Guillaume Collett. London: Bloomsbury Academic.

Bogue, Ronald (2003). Deleuze on Music, Painting and the Arts. New York: Routledge.

DeLanda, Manuel (2002). Intensive Science and Virtual Philosophy. London: Continuum.

DeLanda, Manuel (2006). A New Philosophy of Society: Assemblage Theory and Social Complexity. London: Continuum.

Deleuze, Gilles (1995a). “On Philosophy.” In Negotiations, 1972-1990, trans. Martin Joughin, 135-55. New York: Columbia University Press.

Deleuze, Gilles (1995b). “Control and Becoming” [1990]. In Negotiations, 1972-1990, trans. Martin Joughin, 169-76. New York: Columbia University Press.

Deleuze, Gilles (1995c). “Postscript on Control Societies” [1990]. In Negotiations, 19721990, trans. Martin Joughin, 177-82. New York: Columbia University Press.

Deleuze, Gilles (2004a). “The Method of Dramatization” [1967]. In Desert Islands and Other Texts, 1953-1974, ed. David Lapoujade, trans. Mike Taormina, 94-116. Los Angeles, CA: Semiotext(e).

Deleuze, Gilles (2004b). “How Do We Recognize Structuralism?” [1967]. In Desert Islands and Other Texts, 1953-1974, ed. David Lapoujade, trans. Mike Taormina, 170-92. Los Angeles, CA: Semiotext(e).

Deleuze, Gilles (2004c). Difference and Repetition [1968]. Trans. Paul Patton. London: Continuum.

Deleuze, Gilles (2004d). Logic of Sense [1969]. Trans. Mark Lester and Charles Stivale. London: Continuum.

Deleuze, Gilles (2006a). Nietzsche and Philosophy [1962]. Trans. Hugh Tomlinson. London: Continuum.

Deleuze, Gilles (2006b). “Eight Years Later: 1980 Interview.” In Two Regimes of Madness: Texts and Interviews, 1975-1995, trans. Ames Hodges and Mike Taormina, 175-80. Los Angeles, CA: Semiotext(e).

Deleuze, Gilles (2006c). The Fold: Leibniz and the Baroque [1988]. Trans. Tom Conley. London: Continuum.

Deleuze, Gilles (2007). "Preface to the American Edition of Difference and Repetition" [1994]. In Two Regimes of Madness: Texts and Interviews, 1975-1995, trans. Ames Hodges and Mike Taormina, 300-03. Los Angeles, CA: Semiotext(e).

Deleuze, Gilles, and Félix Guattari (1994). What is Philosophy? [1991]. Trans. Graham 


\section{For Deleuze}

Birchill and Hugh Tomlinson. London: Verso.

Deleuze, Gilles, and Félix Guattari (2004a). Anti-Oedipus: Capitalism and Schizophrenia, Vol. I [1972]. Trans. Robert Hurley, Mark Seem and Helen R. Lane. London: Continuum.

Deleuze, Gilles, and Félix Guattari (2004b). A Thousand Plateaus: Capitalism and Schizophrenia,. Trans. Brian Massumi. London: Continuum.

Deleuze, Gilles, and Félix Guattari (2007). “May '68 Didn’t Happen” [1984]. In Two Regimes of Madness: Texts and Interviews, 1975-1995, trans. Ames Hodges and Mike Taormina, 233-36. Los Angeles, CA: Semiotext(e).

Foucault, Michel (1977). “What is an Author?” In Language, Counter-Memory, Practice: Selected Essays and Interviews, ed. and trans. Donald F. Bouchard, 113-38. Ithaca, NY: Cornell University Press.

Guattari, Félix (1984). “Machine and Structure.” In Molecular Revolution: Psychiatry and Politics, trans. Rosemary Sheed, 111-19. Harmondsworth: Penguin.

Guattari, Félix (1995). Chaosmosis. An Ethico-aesthetic Paradigm [1992]. Trans. Paul Bains and Julian Pefanis. Bloomington: Indiana University Press.

Guattari, Félix (2009). Les Années d'Hiver. 1980-1985. Paris: Les Prairies Ordinaires.

Hallward, Peter (2006). Out of this World: Deleuze and the Philosophy of Creation. London: Verso.

Hardt, Michael, and Antonio Negri (2001). Empire. Cambridge, MA: Harvard University Press.

Jain, Dhruv, ed. (2009). “Deleuze and Marx.” Deleuze Studies 3 Supplement. Edinburgh: Edinburgh University Press.

Lundy, Craig (2012). History and Becoming: Deleuze's Philosophy of Creativity. Edinburgh: Edinburgh University Press.

Maniglier, Patrice (forthcoming). "Problem-Sharing." Theory, Culture \& Society. London: SAGE.

Mengue, Philippe (2003). Deleuze et la question de la démocratie. Paris: Editions L'Harmattan.

Montebello, Pierre (2008). Deleuze. La passion de la pensée. Paris: Vrin.

Sauvagnargues, Anne (2010). Deleuze: L'empirisme transcendantal. Paris: Presses Universitaires de France.

Zourabichvili, François (1994). Deleuze: Une philosophie de l'événement. Paris: Presses Universitaires de France.

Zourabichvili, François (1998). “Deleuze et le possible (de l'involontarisme en politique).” In Gilles Deleuze. Une vie philosophique, ed. Éric Alliez, 335-53. Paris: Synthélabo. 